\title{
Urban Forest Research in Malaysia: A Systematic Review
}

\author{
Keeren Sundara Rajoo ${ }^{1, * \mathbb{C}}$, Daljit Singh Karam ${ }^{2}$, Arifin Abdu ${ }^{3}$, Zamri Rosli ${ }^{1}$ and Geoffery James Gerusu ${ }^{1,4}(\mathbb{C}$ \\ 1 Department of Forestry Science, Faculty of Agricultural Science and Forestry, Universiti Putra Malaysia \\ Bintulu Campus, Nyabau Road, Bintulu 97008, SWK, Malaysia; zamrirosli@upm.edu.my (Z.R.); \\ geoffery@upm.edu.my (G.J.G.) \\ 2 Department of Land Management, Faculty of Agriculture, Universiti Putra Malaysia, \\ Serdang 43400, SGR, Malaysia; daljitsingh@upm.edu.my \\ 3 Department of Forestry Science and Biodiversity, Faculty of Forestry and Environment, \\ Universiti Putra Malaysia, Serdang 43400, SGR, Malaysia; arifinabdu@upm.edu.my \\ 4 Institut Ekosains Borneo, Universiti Putra Malaysia Bintulu Campus, Nyabau Road, \\ Bintulu 97008, SWK, Malaysia \\ * Correspondence: keeren.rajoo@upm.edu.my
}

Citation: Sundara Rajoo, K.; Karam, D.S.; Abdu, A.; Rosli, Z.; James Gerusu, G. Urban Forest Research in Malaysia: A Systematic Review. Forests 2021, 12, 903. https://doi.org/ $10.3390 /$ f12070903

Academic Editor: Elisabetta Salvatori

Received: 30 May 2021

Accepted: 8 July 2021

Published: 12 July 2021

Publisher's Note: MDPI stays neutral with regard to jurisdictional claims in published maps and institutional affiliations.

Copyright: (C) 2021 by the authors. Licensee MDPI, Basel, Switzerland. This article is an open access article distributed under the terms and conditions of the Creative Commons Attribution (CC BY) license (https:// creativecommons.org/licenses/by/ $4.0 /)$.

\begin{abstract}
Sustainable urban development is a major issue in developing countries, namely in environmental and social aspects. Urban forests have the potential to address these issues. Thus, it is not surprising that urban forest research is slowly gaining traction in these regions. However, there have been limited urban forest research reviews focusing on developing countries, especially tropical countries in the global south. Research reviews are vital in identifying the distribution of research themes, hence revealing research gaps and needs. Therefore, this review paper aims to provide a deep insight into the development of urban forest research in Malaysia in the past 20 years. The core purpose of this review is to analyze the distribution of research themes in Malaysia, thus identifying research gaps and needs in developing countries. A total of 43 articles were selected for this review, using the PRISMA framework. The distribution of research articles showed a continuous increase over time, especially for the past five years (2016 to 2021). The reviewed articles were categorized according to five emerging research themes in urban forestry. More than $41 \%$ of the reviewed articles fell under Theme 1 (the physicality of urban forests), with the majority being on biodiversity $(n=10)$. Theme 5 (the governance of urban forest) had the lowest research output $(n=3)$. Urban forestry research is slowly gaining prominence globally including the global south; however, there are obvious preferences in research focus, causing some research questions to be neglected. These research gaps are especially evident in four areas-soil science, ecophysiology, valuation (economics), and environmental justice. These research gaps should be addressed by the scientific community to ensure a thorough and complete research growth pertaining to urban forestry.
\end{abstract}

Keywords: urban forestry; research themes; Malaysia; Southeast Asia; sustainable development; PRISMA

\section{Introduction}

Cities in tropical countries are usually developed at the expense of reduced forest coverages. Nevertheless, due to increased environmental awareness, cities nowadays are developed by integrating forests in city planning. These forested areas are known as urban forests. Urban forest benefits range from ecological well-being to socioeconomic contributions, making it an important part of sustainable urban development [1]. Among the many ecosystem services of urban forests is the recovery function on human health [2]. These health benefits include alleviating depression and anxiety levels, relieving stress, and attention recovery [2]. Additionally, an urban forest also plays a role in environmental improvement. This is due to its part in greenhouse gas absorption, mitigation of urban heat islands, fine dust filtration, noise pollution control, and a wide array of other environmental 
benefits [3]. Based on these benefits, it is safe to conclude that urban forests improve both the mental and physical health of urbanites [2].

Urban forests, alongside urban parks, gardens, and wetlands, are common types of urban green space [4]. The growing global awareness regarding the vital role of urban green spaces has fueled research interest in this field. James et al. (2009) [4] developed a framework to identify key emerging themes and questions in the field of urban green space. The framework was developed based on expert opinion, using the Delphi technique, whereby the experts identified 5 emerging themes and 35 research questions [4]. The following five emerging research themes were identified in this framework were [4]:

(1) Theme 1: The physicality of urban green space:

Covers ecological, soil, air, microclimate, and water quality;

(2) Theme 2: The experience of urban green space:

The psychological and social effects of urban green space;

(3) Theme 3: The valuation of urban green space:

Ecosystem services that contribute toward physical and mental well-being;

(4) Theme 4: The management of urban green space:

The planning, design, maintenance, and resource management of urban green spaces;

(5) Theme 5: The governance of urban green space: The process of making decisions that define expectations, grant authority, and verify performance.

Besides general research on urban green spaces, there has also been growing research interest in the field of urban forestry. Thus, there have been several comprehensive review studies to identify the development and direction of research in this field. Based on the results of previous review studies, it can be concluded that the forerunners in urban forestry research are the USA, Canada, Australia, the UK, and Scandinavian countries [5]. However, there have been limited urban forestry research reviews in developing countries, especially in the global south; one such country being Malaysia. To date, there is still no comprehensive review that specifically addresses urban forestry research in Malaysia.

Malaysia is a developing country located in Southeast Asia, with a population that is approximately 32 million [6] and a total area of $329,847 \mathrm{~km}^{2}$ [6]. The country is divided into two parts that are separated by the South China Sea, one part being Peninsular Malaysia, which borders Thailand and Singapore, while the other part is located on Borneo Island and borders Kalimantan (Indonesia). There are 13 states and 3 federal territories in Malaysia. Malaysia is located close to Earth's equator, providing it a tropical climate. As it is common in tropical climates, Malaysia experiences high humidity and high temperatures all year long [7].

Similar to most developing countries, Malaysia's population has increased exponentially, especially its urban population. Malaysia is considered to be one of Southeast Asia's most urbanized countries, located in one of the world's most rapidly urbanizing regions [8]. Malaysia's urban population increased from 34.3\% in 1971 to $77.2 \%$ in 2020, growing at an average annual rate of $1.67 \%$ [9]. This urban growth is caused by rapid industrialization, causing more people to migrate from rural areas to urban areas, signifying the shift from an agriculture-based economy toward a service- and industrial-based economy. This trend is reflective of the global south. Additionally, similar to other countries in the global south, there is a growing awareness of the need for sustainable urban development, namely, in social and environmental aspects. Thus, it is no surprise that urban forestry research is gaining prominence in these regions. However, a comprehensive review focusing on urban forestry research in the global south and tropical countries is still lacking. Research reviews are vital in identifying the distribution of research themes, therefore revealing research gaps and needs. Nonetheless, we believe that urban forestry research is steadily gaining prominence in developing countries of the global south, and a review will assist in the further development of this research field. Therefore, we conducted a systematic review of Malaysian urban forestry research. Malaysia was selected due to it being a good representation of developing countries in the global south, as it is one of the world's most rapidly urbanizing regions, experiencing rapid industrialization and urban growth. The 
objectives of this paper are (1) to carry out a systematic review of urban forest research in Malaysia that would identify the distribution of research themes and (2) To identify research gaps in Malaysian urban forestry research. The findings of this review would assist in guiding future urban forestry research in developing countries of the global south.

\section{Materials and Methods}

\subsection{Study Area}

This review paper focuses on Malaysia. Malaysia was selected due to it being a good representation of developing countries in the global south. It is located in the center of Southeast Asia, which is one of the world's most rapidly urbanizing regions [8] and is experiencing rapid industrialization alongside rapid urban growth [9]. Its climatic condition is also reflective of the majority of countries in the global south.

There are 13 states and 3 federal territories in Malaysia. Urban forest governance and management fall upon the respective state governments. However, for the federal territories (Putrajaya, Kuala Lumpur, and Labuan), urban forestry is under the purview of the federal government. Differences exist in these states, in terms of population size, median age, and income levels. Moreover, the urbanized areas among these states differ significantly. There are three highly urbanized areas in Malaysia-Selangor, Kuala Lumpur, and Penang. These areas have experienced rapid urban growth, especially during the early 90 s. Besides these areas, Johor, Putrajaya, and Kota Kinabalu (Sabah) have recently experienced urban growth.

\subsection{Selection of Articles}

The systematic literature review for this paper was conducted using the Preferred Reporting Items for Systematic Reviews and Meta-Analysis (PRISMA) framework [10], to evaluate published literature related to urban forestry research in Malaysia (Figure 1). The PRISMA framework was selected for this study since it is widely accepted as a standardized method of conducting reviews [10]. The PRISMA framework includes initial identification through database searching, exclusion of duplicates, title-abstract screening, and full-text article screening for eligibility. We used three databases for this review: Web of Science (WOS), SCOPUS, and Google Scholar.

For WOS and SCOPUS, the search was conducted by title, abstract, and author keywords, with location restricted to Malaysia. We used the following keywords: "urban forest"; "urban park"; "greenspace"; "green space"; "urban green area"; "green infrastructure"; "urban ecology"; "urban trees"; "urban biodiversity"; "urban ecosystem service." In addition, we limited the search to articles after 2000. This is due to our initial search showing very limited urban forestry research before 2000. A total of 472 articles were retrieved from these databases. Google Scholar only allowed title searchers, and our initial search yielded approximately 15,000 articles. However, after the initial manual screening, we discovered that the vast majority of these articles were not within the scope of this review and thus were excluded. Duplicate articles were also removed. Articles were then retrieved and assessed for eligibility. A total of 43 articles were selected for this review based on our criteria (Table A1 in Appendix A). 


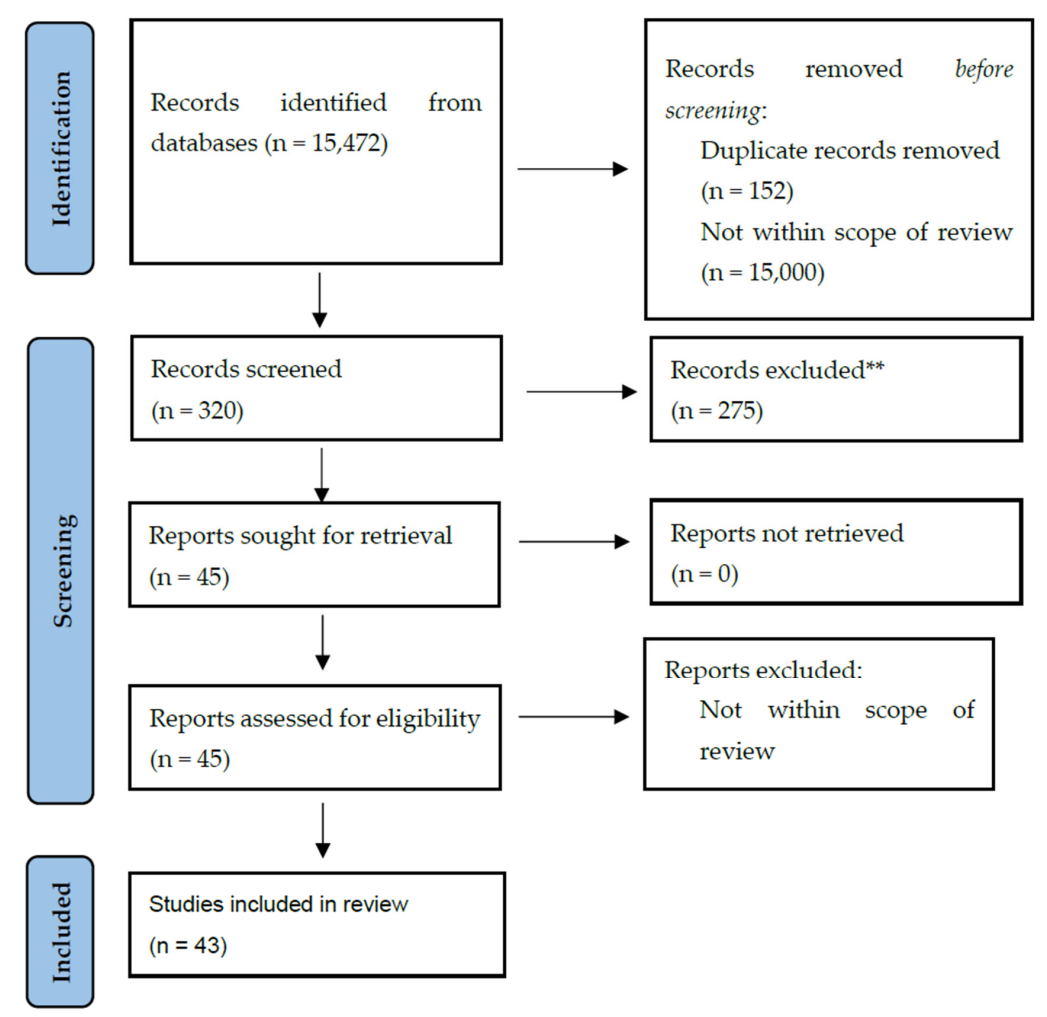

Figure 1. Flowchart of articles retrieved for review using PRISMA framework. Flowchart layout modified from [10].

\subsection{Data Evaluation and Analysis}

Articles selected for the review based on the PRISMA framework were evaluated based on four criteria: year, location, research focus, and research method. Research focus criteria for this review were developed based on the framework by James et al. (2009) [4]. As mentioned previously, the framework by James et al. (2009) [4] was developed to identify key emerging themes and questions in the field of urban green space. The framework was developed based on expert opinion, using the Delphi technique, whereby the experts identified 5 emerging themes and 35 research questions [4]. For this review paper, we modified the framework to better fit urban forestry research by excluding research questions that were not relevant to urban forestry. A total of sixteen research focuses were identified based on five themes, with a sixth category for articles that did not fit any of the following listed research focus:

(1) Theme 1: The physicality of urban forests:

1.1 Food and water;

1.2 Climate regulation;

1.3 Soil science;

1.4 Pollution;

1.5 Ecophysiology;

1.6 Tree health;

1.7 Biodiversity.

(2) Theme 2: The experience of urban forests:

2.1 Sociocultural values;

2.2 Environmental education.

(3) Theme 3: The valuation of urban green forests:

3.1 Urban health;

3.2 Valuation (Economics).

(4) Theme 4: The management of urban forests:

4.1 Sustainable construction; 
4.2 Green space design.

(5) Theme 5: The governance of urban forests:

5.1 Environmental justice;

5.2 Urban forest management;

5.3 Policy and governance.

(6) Others.

For research methods, the articles were categorized based on the following criteria:

1. Field measurements;

2. Surveys/Interviews;

3. Spatial analysis (GIS);

4. Field sampling and laboratory analyses;

5. $\quad$ Modeling/computer simulations;

6. Experiment (nursery/laboratory without sampling);

7. Literature analysis;

8. Field observations;

9. No methods (narrative or descriptive);

10. Others.

Meta-analyses were not performed in this review, due to the heterogeneity of the research papers. Instead, data were analyzed based on article frequency in the four criteria. Patterns were identified based on the distribution of the articles in these criteria to determine which categories were more favored than others and whether there were gaps in research focus.

\section{Results}

\subsection{Distribution of Articles over Time}

The distribution of research articles showed a continuous increase over time (Figure 2). This is especially true for the past five years, that is, from 2016 to 2021 (Figure 3). There were 29 articles from 2016 to 2021, accounting for more than $67 \%$ of research papers in the past two decades. The year 2019 recorded the highest number of publications $(n=9)$. However, this number fell to four in 2020 .

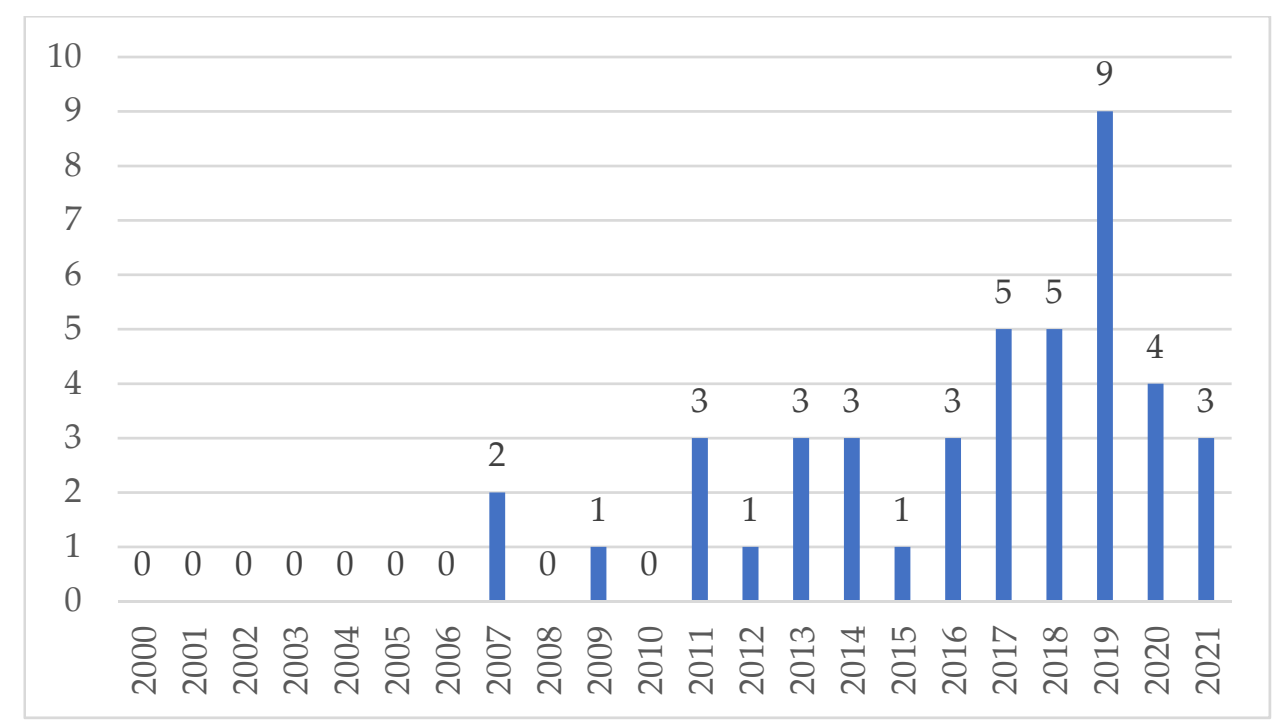

Figure 2. Distribution of articles by year $(n=43)$. 


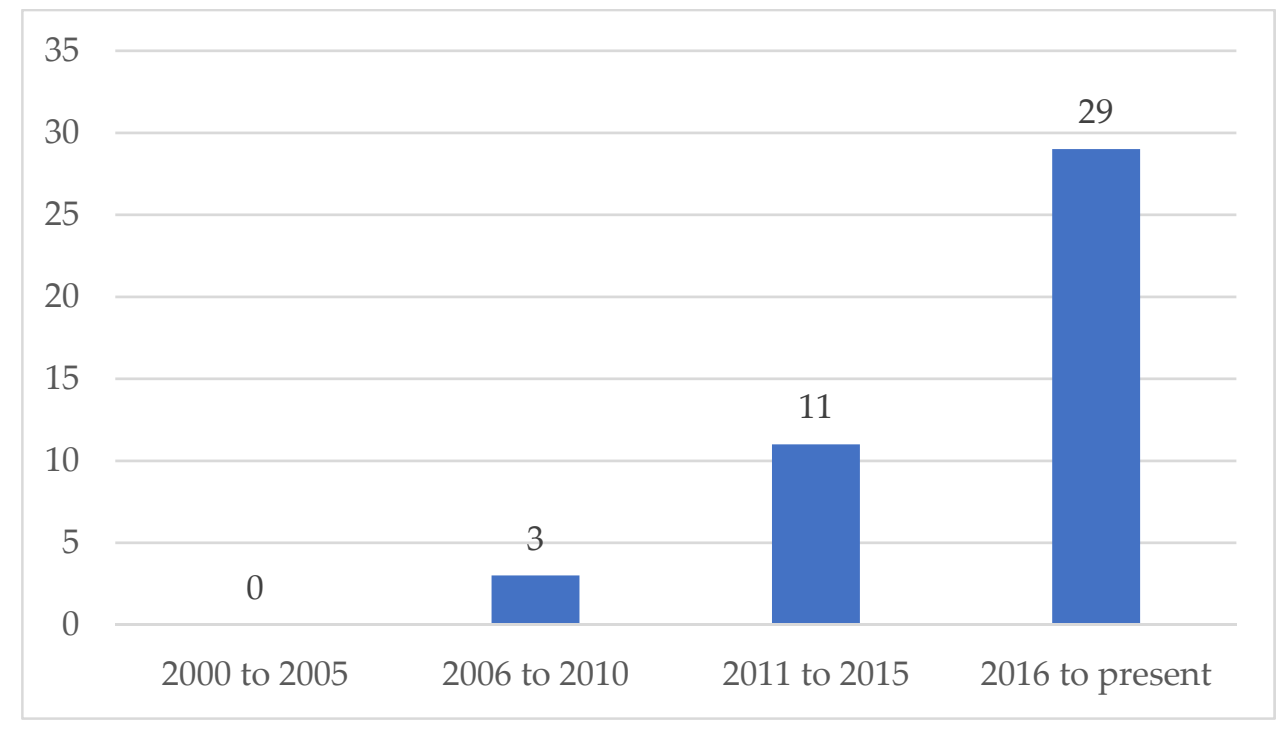

Figure 3. Distribution of articles every five years $(n=43)$.

\subsection{Distribution of Articles Based on Location}

The number of articles varied significantly based on location (Figure 4). The data showed that some states such as Selangor $(n=15)$ and Kuala Lumpur $(n=11)$ accounted for almost one-third of articles while there were four states that only had one paper each, which were Terengganu, Kedah, Sarawak, and N. Sembilan. Moreover, there were states that did not have any papers, for instance, Perak and Kelantan. There were four articles that conducted their studies in multiple locations [11-14]. There was also a study conducted throughout Peninsular Malaysia, whereby the research was on the prevalence of dengue among residents residing on the fringe areas of urban forests [15].

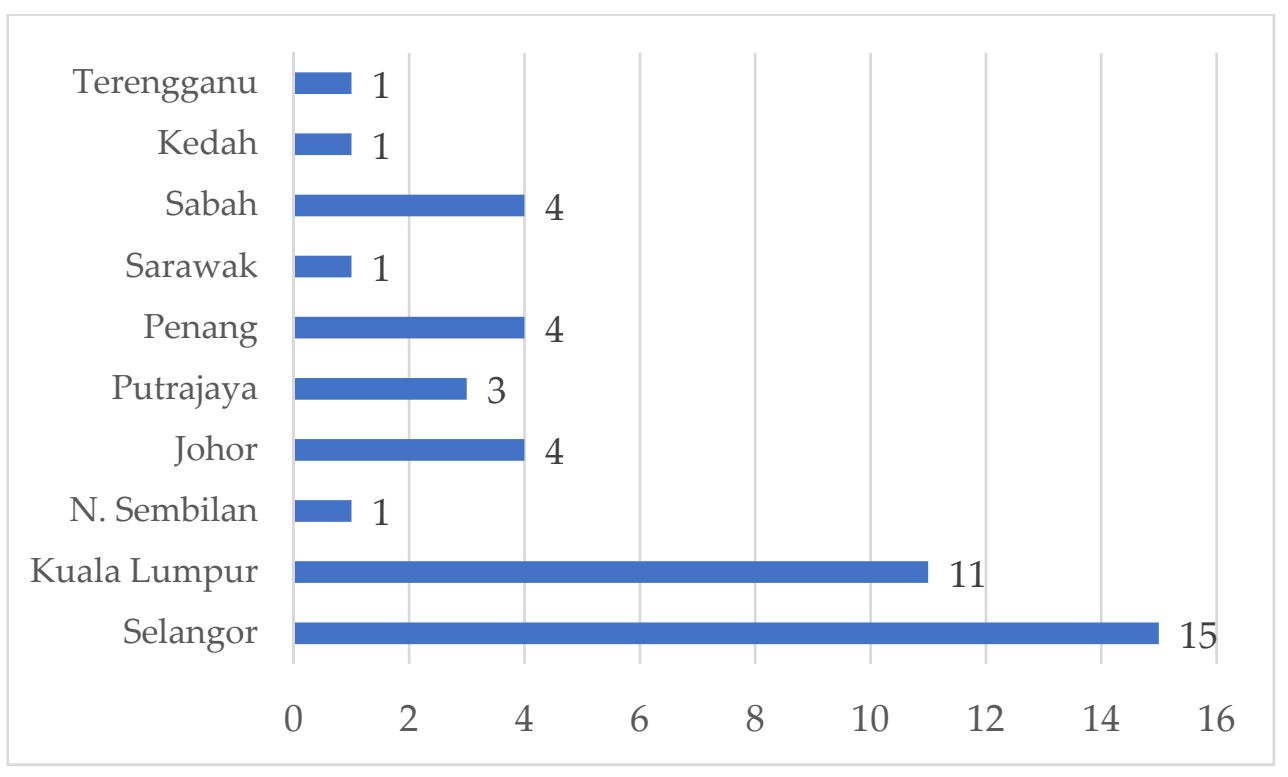

Figure 4. Distribution of articles based on location $(n=45)$.

\subsection{Distribution of Articles Based on Methodology}

Table 1 shows the distribution of articles based on research methodology. Researchers used a wide array of research methodologies in the articles reviewed. The majority of the articles used a single research methodology, while only 10 articles used multiple methodologies. The majority of papers were conducted using surveys or interviews 
( $n=16)$, followed by field measurement $(n=12)$. Literature analysis was also a common methodology $(n=7)$. In most of the articles reviewed, literature analysis was used to provide supplementary data to the research papers [16-19]. None of the articles reviewed used experimentation, that is, research by the nursery, field tests, or laboratory analyses without sampling.

Table 1. Distribution of articles based on research methods.

\begin{tabular}{lc}
\hline \multicolumn{1}{c}{ Methods } & Number of Papers \\
\hline 1. Field measurements & 12 \\
2. Surveys/Interviews & 16 \\
3. Spatial analysis (GIS) & 4 \\
4. Field sampling and laboratory analyses & 5 \\
5. Modeling/computer simulations & 3 \\
6. Experimentation & 0 \\
7. Literature analysis & 7 \\
8. Field observations & 5 \\
9. Others & 0 \\
\hline
\end{tabular}

\subsection{Distribution of Articles Based on Research Themes}

As mentioned previously, research was grouped according to sixteen research focuses based on five themes, with an additional sixth category for articles that did not fit any of the listed research focuses. The overall distribution of research themes in Malaysia showed that some themes were more favored by researchers than others (Figure 5).

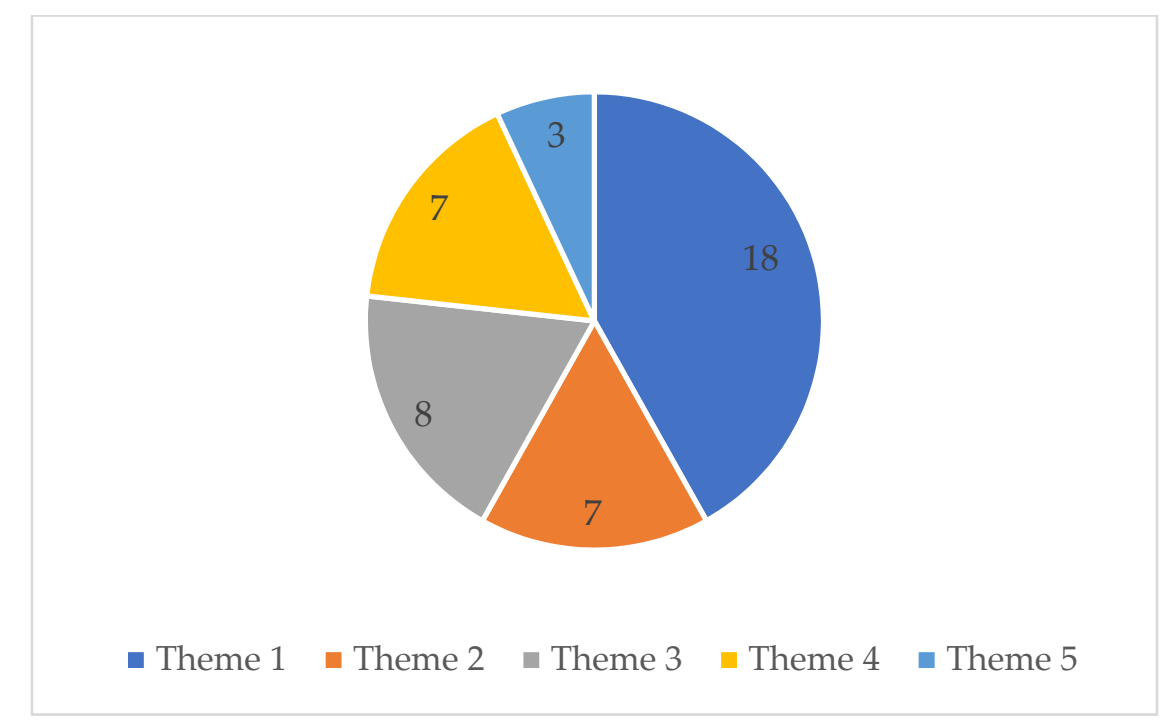

Figure 5. Distribution of articles based on research themes $(n=43)$ : Theme 1 (the physicality of urban green space); Theme 2 (the experience of urban green space); Theme 3 (the valuation of urban green space); Theme 4 (the management of urban green space); Theme 5 (the governance of urban green space).

More than $41 \%$ of the reviewed articles fell under Theme 1: the physicality of urban forests (Table 2). From this theme, the majority were on biodiversity $(n=10)$, followed by climate regulation $(n=3)$, pollution $(n=2)$ and tree health $(n=2)$. As regards biodiversity, most of the reviewed articles were avian studies [17,20-23]. All the articles on climate regulation were studies on urban heat islands $[19,24,25]$ in federal territories (Kuala Lumpur and Putrajaya). Urban heat island is an especially common issue in most parts of the global south, due to the climatic conditions in this region [24]. Authors in [24] reported that increased flora in the form of urban forests did not regulate the urban heat island at 
Putrajaya, but this was more affected by climate change factors. This conclusion was contradictory to the research findings by $[19,25]$, in which it was discovered that reduction in urban forest cover and other land use changes was the biggest contributing factor in urban heat island trends in Kuala Lumpur.

Table 2. Distribution of articles based on research focus $(n=43)$.

\begin{tabular}{lc}
\hline \multicolumn{1}{c}{ Research Focus } & Number of Papers \\
\hline 1.1 Food and water & 1 \\
1.2 Climate regulation & 3 \\
1.3 Soil science & 0 \\
1.4 Pollution & 2 \\
1.5 Ecophysiology & 0 \\
1.6 Tree health & 2 \\
1.7 Biodiversity & 10 \\
2.1 Sociocultural values & 6 \\
2.2 Environmental education & 1 \\
3.1 Urban health & 8 \\
3.2 Valuation (Economics) & 0 \\
4.1 Sustainable construction & 1 \\
4.2 Green space design & 6 \\
5.1 Environmental Justice & 0 \\
5.2 Urban forest management & 2 \\
5.3 Policy and governance & 1 \\
\hline
\end{tabular}

The second most frequent research theme was on Theme 3: the valuation of urban green forests $(n=8)$. It is interesting to note that all of the articles in this theme focused on urban health. These research papers evaluated the relationship between urban forests and urban well-being $[18,26,27]$. In all these papers, the authors discovered that urban forests had a positive effect on urban well-being. Moreover, there was also a study on the potential of urban forests to be a form of preventive medicine via forest therapy [28,29]. Additionally, as mentioned previously, there was also a nationwide study on the role of urban forests in the spread of Dengue [15]. The study found that there was a positive correlation between the occurrence of dengue with the presence of a lake. Furthermore, higher land surface temperatures and lower land elevations also contributed to higher dengue prevalence.

Theme 2 (the experience of urban forests) and Theme 4 (the management of urban forests) both had seven articles each. For Theme 2, the majority of articles were on sociocultural values $(n=6)$. Studies in $[13,30]$ evaluated urban residents' attitudes toward wildlife inhabiting urban forests. Another study [30] demonstrated that Malaysian urban residents had strong preferences toward naturalistic landscape elements such as urban forests. However, they had selective preferences toward wildlife, namely, due to safety concerns. In [13], the authors reaffirmed these findings, stating urban residents exhibited a strong dislike for wild mammals inhabiting urban forests. The study by [31] examined the preference for wetland conservation among urban-rural residents, who both exhibited negative and positive preferences toward conservation of wetlands. The authors of [32] studied the constants that urban residents faced when it came to utilizing urban forests for recreational activities. The study found that facilities and safety were major factors influencing urban residents' usage of urban forests. Only one study in Theme 2 was on environmental education [33].

The majority of articles that fell under Theme 4 were on green space design $(n=6)$. Two articles focused on green space design at Iskandar Malaysia [34,35]. Iskandar Malaysia, formerly known as Iskandar Development Region, is a development corridor in Johor that was established in 2006. The development project aimed to develop a sustainable urbanized area, which included urban forests in the form of green space and wetlands. The current population for this region is almost two million. In [36], the authors focused their study on developing and managing green space in the Klang Valley, a highly urbanized 
region of Selangor. Two studies focused on Kuala Lumpur [37,38]. Only one study in this theme was on sustainable construction, whereby it was a recent study on the role urban forests play in achieving sustainable urban development [39].

Finally, there were only three papers for Theme 5: the governance of urban forests. The study by [16] developed a forest fragmentation index to ease urban forest management based on changes in land use. In [40], the authors evaluated the relationship between different forest management strategies with biodiversity loss, landslides, water pollution, and other health hazards. The study by [41] evaluated the different criteria that should be evaluated when classifying urban green space, to ensure efficient forest governance.

Figure 6 shows the distribution of articles based on research themes by year. Since 2016, there has been an increase in articles focusing on Theme 1: The physicality of urban forests and Theme 2: the experience of urban forests. Half of the articles in 2020 fell under Theme 3: the valuation of urban green forests $(n=2)$. Prior to 2011 , there were no articles for Theme 1 and Theme 2.

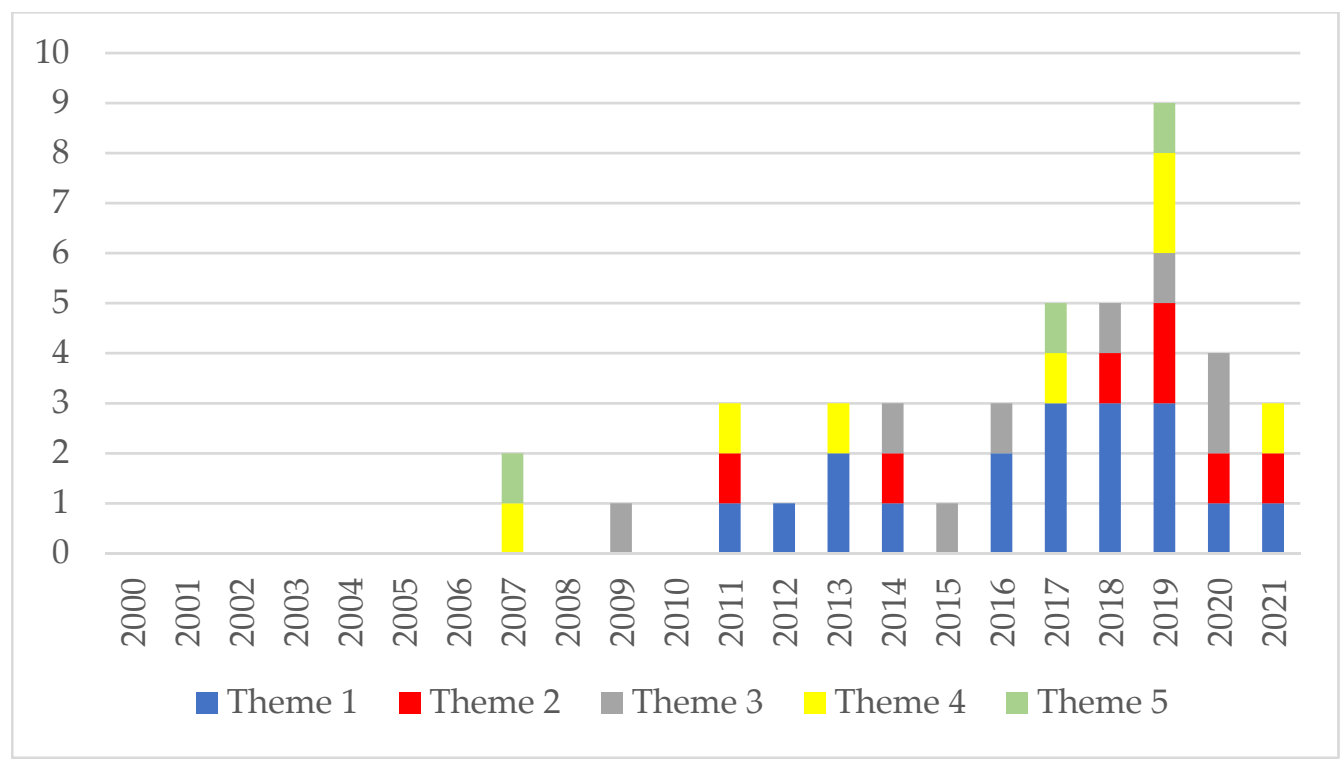

Figure 6. Distribution of articles based on research themes by year $(n=43)$ : Theme 1 (the physicality of urban green space); Theme 2 (The experience of urban green space); Theme 3 (the valuation of urban green space); Theme 4 (The management of urban green space); Theme 5 (the governance of urban green space).

\section{Discussion}

There was a continuous increase in Malaysian urban forestry research, indicating a growing interest in this field. Forestry research is not a novel concept in Malaysia; however, emphasis has always been on natural forests and forest plantations. The growing number of urban forestry research is reflective of Malaysia's rapid urban population growth [9] and growing awareness regarding the need for sustainable development. Urban forestry research has long been practiced in the USA, Canada, Australia, the UK, and Scandinavian countries [5]. The increase in urban forestry research in Malaysia is indicative that naturebased solutions are no longer exclusive to developed countries but are slowly gaining prominence in the global south. It is also likely that earlier studies were not published in English but in the Bahasa Melayu, which is the national language of Malaysia. Most journal databases have a strong English bias, for instance, about $90 \%$ of journals indexed in Scopus being published in English [42].

This growth is especially significant for the past five years, i.e., since $2016(n=29)$. This could be due to the government's short-term development objectives, under the 11th Malaysia Development Plan (2016-2020). Some of the goals of the development plan were to ensure sustainable development and to increase environmental conservation [43]. This 
included research support in terms of funding and thus likely contributed to the increased research output during this period [44]. The highest number of articles was recorded in $2019(n=9)$. However, this figure dropped by more than $55 \%$ in $2020(n=4)$. The significant drop in research output is definitely due to the COVID-19 pandemic as a result of which there were numerous travel restrictions in Malaysia throughout the year in an effort to curb the spread of this global pandemic. Since the majority of urban forestry research is based on fieldwork (Table 1), travel restrictions inhibited this. This trend was evident all over the world [45]. There should be a rise in urban forestry research once the pandemic is successfully contained.

There was an uneven distribution of articles across Malaysia. As expected, there was a higher number of publications in more urbanized locations, mainly in Selangor $(n=15)$, Kuala Lumpur $(n=11)$, Johor $(n=4)$, Sabah $(n=4)$, and Penang $(n=4)$. Rural states had low research output; some states such as Perak, Perlis, and Kelantan had zero articles. It is safe to assume that the research output for these states will increase as they slowly become more urbanized [5].

The varied distribution of research themes meant that researchers believed some research topics to be more relevant than others. The vast majority of articles were in Theme 1: the physicality of urban forests $(n=18)$. The majority of articles in this theme were on biodiversity $(n=10)$, namely, pertaining to avian studies $(n=5)$. Despite Malaysia being a relatively small country, it is one of the world's most megadiverse countries, ranking 12th in the National Biodiversity Index [46]. Being a highly biodiverse country, Malaysia is home to over 780 bird species, with a large number being migratory bird species such as sandpipers, godwits, and plovers [47]. This is due to Malaysia being located on the path of the East Asian-Australasian Flyway, thus making it a vital resting point for migratory birds flying between Australia and East Asia. Birds are a crucial aspect of the biotic community, responding quickly to changes in habitats [48]. Due to this characteristic, birds are often used as bioindicators of environmental quality, environmental stability, and productivity, making them an excellent method to monitor the health of urban forests [48]. Most avian studies in Malaysia focuses on primary and secondary forests [47-49]. Hence, the growing number of avian studies now focusing on urban forests is indicative of the growing role these forests play in preserving biodiversity in the global south.

Besides biodiversity, there was a steadily increasing number of articles on climate regulation, namely, regarding the role of urban forests in addressing urban heat islands $(n=3)$. Urban heat island has been gaining momentum in Southeast Asia since 2004, after receiving considerable attention from atmospheric scientists in the region [19]. The distressing consequences of urban heat islands in Southeast Asia include flash floods, torrential rain, chronic water shortages, heat waves, and even hail storms [19]. The research focus has slowly moved from understanding this phenomenon toward addressing this issue. Therefore, the role of urban forests in regulating urban heat islands has gained traction in the global south, and the findings have been generally favorable [25].

Next to Theme 1, the second-highest frequency of articles was on Theme 3: the valuation of urban green forests $(n=8)$; all articles in this theme were on urban health. Researchers have noted that the valuation of urban forests has recently been more focused on urban health, compared to economic or monetary terms $[50,51]$. This is due to the growing awareness regarding the role urban forests play in maintaining public wellbeing [11]. Moreover, the valuation of green space has been more prevalent in North America and Asia, compared to Europe and Africa [5]. Understanding the relationship between urban forests and urban health is vital for policymakers to evaluate the costbenefit of these urban green spaces [51]. This is especially true for developing countries, where there has been growing concern regarding the deterioration of urban well-being, namely, the urban poor [52]. Policymakers in these regions commonly use urban well-being as a justification for increased expenditure in urban green spaces [34,35]. This also explains the high number of researches on green space design $(n=6)$. The research interest in urban 
health is in line with United Nation's Sustainable Development Goals (SDGs), namely, Goal 3 (Good Health and Well-Being) and Goal 11 (Sustainable Cities and Communities).

There were a high number of researches focusing on sociocultural values $(n=6)$, with topics ranging from society's perception of wildlife [13] to societal attitudes regarding public expenditure on urban green spaces [32]. Globally, studies evaluating the relationship between sociocultural values and urban forests are relatively rare [9]. However, Malaysia, due to being a multicultural and highly diverse country, has always placed a special emphasis in this regard. Sociocultural values dominate all aspects of Malaysian life-from politics to economics [53], and this is also reflective in Malaysian urban forestry research. This trend is most likely prevalent in most developing countries in Southeast Asia [53] but not necessarily in all countries of the global south since the emphasis on sociocultural values in these countries differs greatly from one another.

The low number of articles pertaining to Theme 5: the governance of urban forest $(n=3)$ is not unusual, considering that there is generally a lower number of researches focusing on this field. Nevertheless, there appears to be a recent scientific interest in this field $[40,41]$. This could be due to the 11th Malaysia Development Plan (2016-2020), making sustainable development and environmental conservation hotly contested issues in Malaysian politics [54]. We believe that we will see steady growth in urban forestry research in this theme.

Based on the review data, we have identified research gaps in four areas-soil science, ecophysiology, valuation (economics), and environmental justice. Soil science is an important research scope in urban forestry. Research has shown that compacted urban areas alongside high human activity can cause soil compaction, restricting root growth and impacting tree health [55]. Continuous research is needed in this area to monitor and address this issue. Researchers have also reported the need for more ecophysiology studies in urban forests to better address the effects of climate change and urban heat islands [56]. This is especially true for the global south, where these issues are more prevalent. The valuation of urban forestry in monetary or economic aspects has been widely conducted in Europe [51], yet it is still a relatively new concept in most developing countries [53]. Countries in the global south, especially in Southeast Asia, place a larger emphasis on sociocultural values than on economic valuation [53]. To obtain a more thorough and complete research output in urban forestry, the global south should not overlook this aspect of urban forestry.

Environmental justice is a common research theme in most global south countries due to the large number of indigenous communities still residing within natural ecosystems in these regions [53]. Malaysia is no exception, where environmental justice is a common forestry research topic, namely, pertaining to Orang Asli (the Indigenous People of Malaysia). However, it is unclear why the topic is not studied in urban forestry. The topic is more commonly addressed in North America, especially when compared to Asia [5]. Regardless, there needs to be more research in this area since it is an important aspect of urban forestry practices.

There also appears to be a lack of research pertaining to major global issues, namely, climate change and carbon sequestration. These research topics in the global south are usually focused on natural forests, forest plantations, and agricultural practices. However, urban forests also play a significant role in these issues [56]. Moreover, the reviewed studies did not link their research with international environmental agendas, namely, United Nation's Sustainable Development Goals (SDGs). Urban forests play a vital part in achieving these goals, especially Goal 3 (Good Health and Well-Being), Goal 11 (Sustainable Cities and Communities), Goal 13 (Climate Action), and Goal 15 (Life on Land). Although the majority of the reviewed studies either directly or indirectly help to achieve the SDGs, the authors failed to identify and explain this relationship. 


\section{Conclusions}

To conclude. urban forestry research is slowly gaining prominence in the global south, due to government support and increasing awareness regarding the significance of sustainable urban development. Yet, there are obvious preferences in research focus, causing some research questions to be neglected. These research gaps should be addressed by the scientific community to ensure a thorough and complete research growth pertaining to urban forestry. There is also a need for regional research partnerships in this field, especially among countries with similar climatic conditions. There also needs to be more emphasis on major global issues, such as climate change, and international environmental agendas, namely, SDGs.

There were some limitations to this review. Firstly, the quality of the reviewed articles was not taken into consideration. Secondly, we only reviewed English articles; thus, there is a possibility of articles being excluded due to being in other languages such as Bahasa Melayu. Moreover, there are some Malaysian research journals that are not included in databases such as WOS, SCOPUS, and Google Scholar; thus, these articles too would have been excluded. Although we believe that this review is a good reflection of urban forestry research in the global south; however, this is not true for the sociocultural aspects of urban forestry research. This is due to the emphasis on sociocultural values in Southeast Asia generally being higher than most countries of the global south.

Author Contributions: Conceptualization, K.S.R. and D.S.K.; methodology, K.S.R. and D.S.K.; software, D.S.K.; validation, K.S.R., D.S.K. and A.A.; formal analysis, K.S.R.; resources, A.A.; data curation, D.S.K.; writing—original draft preparation, K.S.R.; writing—review and editing, Z.R. and G.J.G.; visualization, K.S.R.; supervision, K.S.R. All authors have read and agreed to the published version of the manuscript.

Funding: This research received no external funding.

Conflicts of Interest: The authors declare no conflict of interest.

Appendix A

Table A1. Articles selected for this review $(n=43)$.

\begin{tabular}{|c|c|c|c|c|c|c|}
\hline No. & Study & Year & Location & Research Focus & Research Method & Database/Source \\
\hline 1 & $\begin{array}{c}\text { Abdullah and } \\
\text { Nakagoshi, 2007 [16] }\end{array}$ & 2007 & Selangor & $\begin{array}{l}5.3 \text { Policy and } \\
\text { governance }\end{array}$ & $\begin{array}{l}\text { 5. Modeling/computer } \\
\text { simulations } \\
\text { 7. Literature analysis }\end{array}$ & $\begin{array}{l}\text { WOS } \\
\text { Scopus }\end{array}$ \\
\hline 2 & Ho and Fong, 2007 [34] & 2007 & Johor & $\begin{array}{c}\text { 4.2 Green space } \\
\text { design }\end{array}$ & 7. Literature analysis & Scopus \\
\hline 3 & $\begin{array}{l}\text { Paramasvaran et al. } \\
2009 \text { [11] }\end{array}$ & 2009 & $\begin{array}{l}\text { Kuala Lumpur, } \\
\text { Selangor } \\
\text { N. Sembilan }\end{array}$ & 3.1 Urban health & 1. Field measurements & Google scholar \\
\hline 4 & Mohamad, 2011 [30] & 2011 & Selangor & $\begin{array}{l}2.1 \text { Sociocultural } \\
\text { values }\end{array}$ & 2. Surveys/Interviews & Google scholar \\
\hline 5 & $\begin{array}{c}\text { Nor-Akmar et al., } \\
2011[36]\end{array}$ & 2011 & Selangor & $\begin{array}{l}\text { 4.2 Green space } \\
\text { design }\end{array}$ & $\begin{array}{l}\text { 2. Surveys/Interviews } \\
\text { 7. Literature analysis }\end{array}$ & $\begin{array}{l}\text { Google scholar } \\
\text { Scopus }\end{array}$ \\
\hline 6 & $\begin{array}{l}\text { Sreetheran et al., } \\
2011 \text { [57] }\end{array}$ & 2011 & Kuala Lumpur & 1.6 Tree health & 1. Field measurements & Google scholar \\
\hline 7 & $\begin{array}{l}\text { Idilfitri and Mohamad, } \\
2012 \text { [17] }\end{array}$ & 2012 & Selangor & 1.7 Biodiversity & $\begin{array}{l}\text { 2. Surveys/Interviews } \\
\text { 7. Literature analysis }\end{array}$ & $\begin{array}{l}\text { WOS } \\
\text { Scopus }\end{array}$ \\
\hline 8 & Ho et al., 2013 [35] & 2013 & Johor & $\begin{array}{c}\text { 4.2 Green space } \\
\text { design }\end{array}$ & $\begin{array}{l}\text { 5. Modeling/computer } \\
\text { simulations }\end{array}$ & $\begin{array}{c}\text { WOS } \\
\text { Scopus }\end{array}$ \\
\hline
\end{tabular}


Table A1. Cont.

\begin{tabular}{|c|c|c|c|c|c|c|}
\hline No. & Study & Year & Location & Research Focus & Research Method & Database/Source \\
\hline 9 & $\begin{array}{l}\text { Mohamad et al., } \\
2013 \text { [58] }\end{array}$ & 2013 & Selangor & 1.7 Biodiversity & $\begin{array}{l}\text { 1. Field measurements } \\
\text { 8. Field observations }\end{array}$ & Scopus \\
\hline 10 & Salleh et al., 2013 [24] & 2013 & Putrajaya & $\begin{array}{l}1.2 \text { Climate } \\
\text { regulation }\end{array}$ & $\begin{array}{l}\text { 5. Modeling/computer } \\
\text { simulations }\end{array}$ & Scopus \\
\hline 11 & $\begin{array}{l}\text { Karuppannam et al., } \\
2014 \text { [20] }\end{array}$ & 2014 & Kuala Lumpur & 1.7 Biodiversity & 8. Field observations & Google scholar \\
\hline 12 & Malek et al., 2014 [12] & 2014 & $\begin{array}{l}\text { Kuala Lumpur } \\
\text { Selangor }\end{array}$ & $\begin{array}{l}2.1 \text { Sociocultural } \\
\text { values }\end{array}$ & 2. Surveys/Interviews & $\begin{array}{c}\text { Google Scholar } \\
\text { WOS } \\
\text { Scopus }\end{array}$ \\
\hline 13 & $\begin{array}{l}\text { Mansor and Harun, } 2014 \\
\text { [26] }\end{array}$ & 2014 & Malaysia & 3.1 Urban health & 7. Literature analysis & Scopus \\
\hline 14 & Abdullah et al., 2015 [59] & 2015 & Selangor & 3.1 Urban health & 2. Surveys/Interviews & $\begin{array}{l}\text { WOS } \\
\text { Scopus }\end{array}$ \\
\hline 15 & Aida et al., 2016 [21] & 2016 & Selangor & 1.7 Biodiversity & 1. Field measurements & $\begin{array}{c}\text { WOS } \\
\text { Scopus }\end{array}$ \\
\hline 16 & Foo, 2016 [18] & 2016 & Selangor & 3.1 Urban health & $\begin{array}{l}\text { 2. Surveys/Interviews } \\
\text { 7. Literature analysis }\end{array}$ & $\begin{array}{l}\text { Google scholar } \\
\text { WOS } \\
\text { Scopus }\end{array}$ \\
\hline 17 & $\begin{array}{l}\text { Jusoh and Hashim, } 2016 \\
\text { [60] }\end{array}$ & 2016 & Kuala Lumpur & 1.7 Biodiversity & 1. Field measurements & Google scholar \\
\hline 18 & Jasmani et al., 2017 [22] & 2017 & Selangor & 1.7 Biodiversity & 1. Field measurements & $\begin{array}{l}\text { Scopus } \\
\text { WOS }\end{array}$ \\
\hline 19 & Kanniah, 2017 [37] & 2017 & Kuala Lumpur & $\begin{array}{c}\text { 4.2 Green space } \\
\text { design }\end{array}$ & 3. Spatial analysis (GIS) & $\begin{array}{l}\text { WOS } \\
\text { Scopus }\end{array}$ \\
\hline 20 & Masum et al., 2017 [40] & 2017 & Penang & $\begin{array}{l}5.2 \text { Urban forest } \\
\text { management }\end{array}$ & 3. Spatial analysis (GIS) & Scopus \\
\hline 21 & $\begin{array}{c}\text { Norbaiyah et al., } 2017 \\
{[61]} \\
\end{array}$ & 2017 & Putrajaya & 1.6 Tree health & 1. Field measurements & Google scholar \\
\hline 22 & $\begin{array}{c}\text { Sabtu and Majid, } 2017 \\
\text { [62] }\end{array}$ & 2017 & Penang & 1.7 Biodiversity & $\begin{array}{l}\text { 4. Field sampling and } \\
\text { laboratory analyses }\end{array}$ & Scopus \\
\hline 23 & Karin et al., 2018 [63] & 2018 & Sarawak & 1.7 Biodiversity & 1. Field measurements & Google scholar \\
\hline 24 & $\begin{array}{c}\text { Majuakim et al.., } 2018 \\
{[64]}\end{array}$ & 2018 & Sabah & 1.7 Biodiversity & 1. Field measurements & Google Scholar \\
\hline 25 & Muslim et al., 2018 [13] & 2018 & $\begin{array}{c}\text { Selangor Kuala } \\
\text { Lumpur } \\
\text { Putrajaya }\end{array}$ & $\begin{array}{l}2.1 \text { Sociocultural } \\
\text { values }\end{array}$ & 2. Surveys/Interviews & $\begin{array}{l}\text { Google scholar } \\
\text { Scopus }\end{array}$ \\
\hline 26 & Nath et al. 2018 [27] & 2018 & Kuala Lumpur & 3.1 Urban health & 2. Surveys/Interviews & $\begin{array}{c}\text { Google Scholar } \\
\text { WOS } \\
\text { Scopus }\end{array}$ \\
\hline 27 & $\begin{array}{l}\text { Ramakreshnan et al., } \\
2018 \text { [19] }\end{array}$ & 2018 & Kuala Lumpur & $\begin{array}{l}1.2 \text { Climate } \\
\text { regulation }\end{array}$ & $\begin{array}{l}\text { 5. Modeling/computer } \\
\text { simulations } \\
\text { 7. Literature analysis } \\
\text { 8. Field observations }\end{array}$ & Scopus \\
\hline 28 & Dreyer et al., 2019 [33] & 2019 & Selangor & $\begin{array}{c}2.2 \text { Environmental } \\
\text { education }\end{array}$ & 2. Surveys/Interviews & $\begin{array}{l}\text { Google Scholar } \\
\text { Scopus }\end{array}$ \\
\hline 29 & Hamid et al., 2019 [14] & 2019 & $\begin{array}{l}\text { Kuala Lumpur } \\
\text { Penang } \\
\text { Selangor Kedah }\end{array}$ & 1.4 Pollution & $\begin{array}{l}\text { 4. Field sampling and } \\
\text { laboratory analyses }\end{array}$ & $\begin{array}{l}\text { Google scholar } \\
\text { Scopus }\end{array}$ \\
\hline
\end{tabular}


Table A1. Cont.

\begin{tabular}{|c|c|c|c|c|c|c|}
\hline No. & Study & Year & Location & Research Focus & Research Method & Database/Source \\
\hline 30 & Hassan et al., 2019 [31] & 2019 & Terengganu & $\begin{array}{l}2.1 \text { Sociocultural } \\
\text { values }\end{array}$ & 2. Surveys/Interviews & $\begin{array}{l}\text { WOS } \\
\text { Scopus }\end{array}$ \\
\hline 31 & Kasim et al. 2019 [38] & 2019 & Kuala Lumpur & $\begin{array}{c}\text { 4.2 Green space } \\
\text { design }\end{array}$ & 3. Spatial analysis (GIS) & $\begin{array}{l}\text { Google Scholar } \\
\text { Scopus }\end{array}$ \\
\hline 32 & Lim and Mojiol, 2019 [23] & 2019 & Sabah & 1.7 Biodiversity & 1. Field measurements & Google scholar \\
\hline 33 & Nor et al., 2019 [41] & 2019 & Sabah & $\begin{array}{l}\text { 5.2 Urban forest } \\
\text { management }\end{array}$ & 3. Spatial analysis (GIS) & Google scholar \\
\hline 34 & Rajoo et al., 2019 [28] & 2019 & Selangor & 3.1 Urban health & $\begin{array}{l}\text { 1. Field measurements } \\
\text { 2. Surveys/Interviews }\end{array}$ & $\begin{array}{l}\text { WOS } \\
\text { Scopus }\end{array}$ \\
\hline 35 & Shen et al., 2019 [65] & 2019 & Sabah & $\begin{array}{c}\text { 4.2 Green space } \\
\text { design }\end{array}$ & 8. Field observations & Google scholar \\
\hline 36 & Yin et al., 2019[66] & 2019 & Penang & 1.4 Pollution & $\begin{array}{l}\text { 4. Field sampling and } \\
\text { laboratory analyses } \\
\text { 8. Field observations }\end{array}$ & Google scholar \\
\hline 37 & $\begin{array}{l}\text { Abd-Jamil et al., } \\
\quad 2020 \text { [15] }\end{array}$ & 2020 & $\begin{array}{l}\text { Peninsular } \\
\text { Malaysia }\end{array}$ & 3.1 Urban health & $\begin{array}{l}\text { 2. Surveys/Interviews } \\
\text { 4. Field sampling and } \\
\text { laboratory analyses }\end{array}$ & Google scholar \\
\hline 38 & Harun et al., 2020 [25] & 2020 & Kuala Lumpur & $\begin{array}{l}1.2 \text { Climate } \\
\text { regulation }\end{array}$ & 1. Field measurements & $\begin{array}{c}\text { WoS } \\
\text { Scopus }\end{array}$ \\
\hline 39 & $\begin{array}{l}\text { Kerishnan et al., } \\
2020 \text { [32] }\end{array}$ & 2020 & Kuala Lumpur & $\begin{array}{l}2.1 \text { Sociocultural } \\
\text { values }\end{array}$ & 2. Surveys/Interviews & $\begin{array}{l}\text { WOS } \\
\text { Scopus }\end{array}$ \\
\hline 40 & Rajoo et al., 2020 [29] & 2020 & Selangor & 3.1 Urban health & $\begin{array}{l}\text { 1. Field measurements } \\
\text { 2. Surveys/Interviews }\end{array}$ & $\begin{array}{l}\text { WOS } \\
\text { Scopus }\end{array}$ \\
\hline 41 & Mohamed et al., 2021[39] & 2021 & Selangor & $\begin{array}{l}\text { 4.1 Sustainable } \\
\text { construction }\end{array}$ & 2. Surveys/Interviews & Google scholar \\
\hline 42 & $\begin{array}{l}\text { Moser and Avery, } \\
2021 \text { [67] }\end{array}$ & 2021 & Johor & $\begin{array}{c}\text { 2.1 Sociocultural } \\
\text { values }\end{array}$ & 2. Surveys/Interviews & $\begin{array}{l}\text { Google scholar } \\
\text { WOS } \\
\text { Scopus }\end{array}$ \\
\hline 43 & Pak et al., 2021 [68] & 2021 & Johor & 1.1 Food and Water & $\begin{array}{l}\text { 4. Field sampling and } \\
\text { laboratory analyses }\end{array}$ & Scopus \\
\hline
\end{tabular}

\section{References}

1. Sivarajah, S.C.; Thomas, S.M.; Smith, S. Evaluating the ultraviolet protection factors of urban broadleaf and conifer trees in public spaces. Urban For. Urban Green. 2020, 51, 126679. [CrossRef]

2. Meyer, K.; Botsch, K. Do forest and health professionals presume that forests offer health benefits, and is cross-sectional cooperation conceivable? Urban For. Urban Green. 2017, 27, 127-137. [CrossRef]

3. Kim, S.J.; Lee, T.J.; Hyun, S.S. Estimating the economic value of urban forest parks: Focusing on restorative experiences and environmental concerns. J. Destin. Mark. Manag. 2021, 20, 100603. [CrossRef]

4. James, P.; Tzoulas, K.; Adams, M.D.; Barber, A.; Box, J.; Breuste, J.; Elmqvist, T.; Frith, M.; Gordon, C.; Greening, K.L.; et al. Towards an integrated understanding of green space in the European built environment. Urban For. Urban Green. 2009, 8, 65-75. [CrossRef]

5. Ostoic, S.K.; Salbitano, F.; Borelli, S.; Verlic, A. Urban forest research in the Mediterranean: A systematic review. Urban For. Urban Green. 2018, 21, 185-196. [CrossRef]

6. Michel Devadoss, P.S.; Agamuthu, P.; Mehran, S.; Santha, C.; Fauziah, S. Implications of municipal solid waste management on greenhouse gas emissions in Malaysia and the way forward. Waste Manag. 2001, 119, 135-144. [CrossRef] [PubMed]

7. Tan, M.L.; Juneng, L.; Tangang, F.T.; Chung, J.X.; Radin Firdaus, R.B. Changes in temperature extremes and their relationship with ENSO in Malaysia from 1985 to 2018. Int. J. Climatol. 2020, 41. [CrossRef]

8. Alias, A.; Ali, A.S.; Wai, C.K. New urbanism and township developments in Malaysia. Urban Des. Int. 2010, 16, 76-93. [CrossRef]

9. Shamsudin, M.N. Farming in the City. 2017. Available online: https://www.nst.com.my/opinion/columnists/2017/07/259309 / farming-city (accessed on 3 April 2021). 
10. Moher, D.; Liberati, A.; Tetzlaff, J.; Altman, D.G.; PRISMA Group. Preferred reporting items for systematic reviews and meta-analyses: The PRISMA statement. PLoS Med. 2009, 6, e1000097. [CrossRef]

11. Paramasvaran, S.; Sani, R.A.; Hassan, L.; Krishnasamy, M.; Jeffery, J.; Oothuman, P.; Salleh, I.; Lim, K.H.; Sumarni, M.G.; Santhana, R.L. Ectoparasite fauna of rodents and shrews from four habitats in Kuala Lumpur and the states of Selangor and Negeri Sembilan, Malaysia and its public health significance. Trop. Biomed. 2009, 26, 303-311. [PubMed]

12. Malek, N.A.; Mariapan, M.; Rahman, N.I.A.A. Community participation in quality assessment for green open spaces in Malaysia. Procedia-Soc. Behav. Sci. 2014, 168, 219-228. [CrossRef]

13. Muslim, H.F.M.; Tetsuro, H.; Shinya, N.; Yahya, N.A. Nature experience promotes preference for and willingness to coexist with wild animals among urban and suburban residents in Malaysia. Ecol. Process. 2018, 7, 12.

14. Hamid, H.H.A.; Latif, M.T.; Nadzir, M.S.M.; Uning, R.; Khan, M.F.; Kannan, N. Ambient BTEX levels over urban, suburban and rural areas in Malaysia. Air Qual. Atmos. Health 2019, 12, 341-351. [CrossRef]

15. Abd-Jamil, J.; Ngui, R.; Nellis, S.; Fauzi, R.; Lim, A.L.Y.; Chinna, K.; Khor, C.-S.; AbuBakar, S. Possible factors influencing the seroprevalence of dengue among residents of the forest fringe areas of Peninsular Malaysia. J. Trop. Med. 2020, 2020, 1019238. [CrossRef] [PubMed]

16. Abdullah, S.A.; Nakagoshi, N. Forest fragmentation and its correlation to human land use change in the state of Selangor, peninsular Malaysia. For. Ecol. Manag. 2007, 241, 39-48. [CrossRef]

17. Idilfitri, S.; Mohamad, N.H.N. Role of ornamental vegetation for birds' habitats in urban parks: Case study FRIM, Malaysia Procedia-Soc. Behav. Sci. 2012, 68, 894-909. [CrossRef]

18. Foo, C.H. Linking forest naturalness and human wellbeing-A study on public's experiential connection to remnant forests within a highly urbanized region in Malaysia. Urban For. Urban Green. 2016, 16, 13-24. [CrossRef]

19. Ramakreshnan, L.; Aghamohammadi, N.; Fong, C.S.; Ghaffarianhoseini, A.; Ghaffarianhoseini, A.; Wong, L.P.; Hassan, N.; Sulaiman, N.M. A critical review of urban heat island phenomenon in the context of Greater Kuala Lumpur, Malaysia. Sustain. Cities Soc. 2018, 39, 99-113. [CrossRef]

20. Karuppannam, S.; Baharuddin, Z.M.; Sivam, A.; Daniels, C.B. Urban green space and urban biodiversity: Kuala Lumpur, Malaysia. J. Sustain. Dev. 2014, 791, 16.

21. Aida, N.; Sasidhran, S.; Kamarudin, N.; Aziz, N.; Puan, C.L.; Azhar, B. Woody trees, green space and park size improve avian biodiversity in urban landscapes of Peninsular Malaysia. Ecol. Indic. 2016, 69, 176-183. [CrossRef]

22. Jasmani, Z.; Ravn, H.P.; van den Bosch, C.C.K. The influence of small urban parks characteristics on bird diversity: A case study of Petaling Jaya, Malaysia. Urban Ecosyst. 2017, 20, 227-243. [CrossRef]

23. Lim, W.-S.; Mojiol, A.R. A preliminary assessment on avian community in the urban forest of Universiti Malaysia Sabah. Trans. Sci. Technol. 2019, 6, 292-297.

24. Salleh, S.A.; Latif, Z.A.; Mohd, W.M.N.W.; Chan, A. Factors contributing to the formation of an urban heat Island in Putrajaya, Malaysia. Procedia-Soc. Behav. Sci. 2013, 105, 840-850. [CrossRef]

25. Harun, Z.; Reda, E.; Abdulrazzaq, A.; Abbas, A.A.; Yusup, Y.; Zaki, S.A. Urban heat island in the modern tropical Kuala Lumpur: Comparative weight of the different parameters. Alex. Eng. J. 2020, 59, 4475-4489. [CrossRef]

26. Mansor, M.; Harun, N.Z. Health issues and awareness and the significant of green space for health promotion in Malaysia. Procedia-Soc. Behav. Sci. 2014, 153, 209-220. [CrossRef]

27. Nath, T.K.; Han, S.S.Z.; Lechner, A.M. Urban green space and well-being in Kuala Lumpur, Malaysia. Urban For. Urban Green. 2018, 36, 34-41. [CrossRef]

28. Rajoo, K.S.; Karam, D.S.; Aziz, N.A.A. Developing an effective forest therapy program to manage academic stress in conservative societies: A multi-disciplinary approach. Urban For. Urban Green. 2019, 43, 126353. [CrossRef]

29. Rajoo, K.S.; Karam, D.S.; Wook, N.-F.; Abdullah, M.-Z. Forest therapy: An environmental approach to managing stress in middle-aged working women. Urban For. Urban Green. 2020, 55, 126853. [CrossRef]

30. Mohamad, N.H.N. Urban residents' attitudes toward wildlife in their neighbourhoods: The case study of Klang Valley, Malaysia. J. Malays. Inst. Plan. 2011, 9, 19-36. [CrossRef]

31. Hassan, S.; Olsen, S.B.; Thorsen, B.J. Urban-rural divides in preferences for wetland conservation in Malaysia. Land Use Policy 2019, 84, 226-237. [CrossRef]

32. Kerishnan, P.B.; Maruthaveeran, S.; Maulan, S. Investigating the usability pattern and constraints of pocket parks in Kuala Lumpur, Malaysia. Urban For. Urban Green. 2020, 50, 126647. [CrossRef]

33. Dreyer, J.M.; Yahya, N.A.; Kadir, N.A.A. Visitor's perception of the Forest Research Institute of Malaysia (FRIM) as an urban open space for environmental learning: Results of a qualitative study. Environ. Dev. Sustain. 2019, 21, 1933-1945. [CrossRef]

34. Ho, C.S.; Fong, W.K. Planning for low carbon cities-The case of Iskandar Development Region, Malaysia. In Toward Establishing Sustainable Planning and Governance II; Sungkyunkwan University: Seoul, Korea, 2007.

35. Ho, C.S.; Matsuoka, Y.; Simson, J.; Gomi, K. Low carbon urban development strategy in Malaysia-The case of Iskandar Malaysia development corridor. Habitat Int. 2013, 37, 43-51. [CrossRef]

36. Nor-Akmar, A.A.N.; Konijnendijk, C.C.; Sreetheran, M.; Nilsson, K. Greenspace planning and management in Klang Valley, Peninsular Malaysia. Arboric. Urban For. 2011, 37, 99-107.

37. Kanniah, K.D. Quantifying green cover change for sustainable urban planning: A case of Kuala Lumpur, Malaysia. Urban For. Urban Green. 2017, 27, 287-304. [CrossRef] 
38. Kasim, J.A.; Yusof, M.J.M.; Shafri, H.Z.M. Monitoring urban green space (UGS) changes by using high resolution aerial imagery: A case study of Kuala Lumpur, Malaysia. Pertanika J. Sci. Technol. 2019, 27, 1971-1990.

39. Mohamed, N.; Othman, N.; Ariffin, M.H. The potential of urban forest park for sustainable city. J. Malays. Inst. Plant. 2021, 10, 67-80. [CrossRef]

40. Masum, K.M.; Mansor, A.; Sah, S.A.M.; Lim, H.S. Effect of differential forest management on land-use-change (LUC) in a tropical hill forest of Malaysia. J. Environ. Manag. 2017, 200, 468-474. [CrossRef]

41. Nor, A.N.M.; Abdullah, S.A. Developing urban green space classification system using multi-criteria: The case of Kuala Lumpur City, Malaysia. J. Landsc. Ecol. 2019, 12, 16-36. [CrossRef]

42. Weijen, D. The Language of (Future) Scientific Communication. Research Trends 31. 2012. Available online: https://www. researchtrends.com/issue-31-november2012/the-language-of-future-scientific-communication/ (accessed on 5 June 2021).

43. Ngu, H.K.; Lee, M.D.; Osman, M.S.B. Review on current challenges and future opportunities in Malaysia sustainable manufacturing: Remanufacturing industries. J. Clean. Prod. 2020, 273, 123071. [CrossRef]

44. Vermund, S.H.; Karim, S.A. Chapter 39-Governmental Support of Research. In Clinical and Translational Science, 2nd ed.; Academic Press: Cambridge, MA, USA, 2017; ISBN 9780128021019.

45. Miki, Y.; Chubachi, N.; Imamura, F.; Yaegashi, N.; Ito, K. Impact of COVID-19 restrictions on the research environment and motivation of researchers in Japan. Prog. Disaster Sci. 2020, 8, 100128. [CrossRef] [PubMed]

46. Bjelle, E.K.; Kuipers, K.; Verones, F.; Wood, R. Trends in national biodiversity footprints of land use. Ecol. Econ. 2021, 185, 107059. [CrossRef]

47. Mansor, M.S.; Rozali, F.Z.; Abdullah, N.A.; Nor, S.; Ramli, R. How important is aerial leaf litter for insectivorous birds foraging in a Malaysian tropical forest? Glob. Ecol. Conserv. 2019, 20, e00722. [CrossRef]

48. Rajpar, M.N.; Zakaria, M. Bird Species Abundance and Their Correlationship with Microclimate and Habitat Variables at Natural Wetland Reserve, Peninsular Malaysia. Int. J. Zool. 2011, 2011, 758573. [CrossRef]

49. Martins, C.; Olaniyi, O.; Zakaria, M. Ecological factors and spatial heterogeneity of Terrestrial Birds in Peninsular Malaysia. In Proceedings of the IOP Conference Series Earth and Environmental Science, Al-Qadisiyah, Iraq, 24-25 March 2021; Volume 736, p. 012035. [CrossRef]

50. Eaton, E.; Hunt, A. Valuation of the urban environment by its potential impact on human health: A modelling study for the UPSTREAM project. Lancet Planet. Health 2019, 3, S4. [CrossRef]

51. Chen, X. Monetary valuation of urban nature's health effects: Asystematic review. J. Environ. Plan. Manag. 2020, 63, 1716-1737. [CrossRef]

52. Sherina, M.S.; Rampal, L.; Hejar, A.R.; Ahmad, R.; Yunus, M.A. Prevalence of urban poor and its health related factors in the state of selangor, Malaysia. Malays. J. Med. Health Sci. 2011, 7, 17-25.

53. Evers, H.D. Southeast Asia: Sociocultural Aspects. In International Encyclopedia of the Social E Behavioral Sciences, 2nd ed.; Elsevier: Amsterdam, The Netherlands, 2015; ISBN 9780080970875. [CrossRef]

54. Olsen, D.K. Pollution, Water Cuts Strengthen Calls for Environmental Law Reform in Malaysia. Mongabay. 2020. Available online: https:/ / news.mongabay.com/2020/12/pollution-water-cuts-strengthen-calls-for-environmental-law-reform-in-malaysia/ (accessed on 4 June 2021).

55. Jim, C.Y. Resolving intractable soil constraints in urban forestry through research-practice synergy. Socio-Ecol. Pract. Res. 2019, 1, 41-53. [CrossRef]

56. Bussotti, F.; Pollastrini, M.; Killi, D.; Ferrini, F.; Fini, A. Ecophysiology of urban trees in a perspective of climate change. Agrochimica 2014, 58, 247-268.

57. Sreetheran, M.; Adnan, M.; Azuar, A.K.K. Street tree inventory and tree risk assessment of selected major roads in Kuala Lumpur, Malaysia. Arboric. Urban For. 2011, 37, 226-235.

58. Mohamad, N.H.N.; Idilfitri, S.; Thani, S.K.S.O. Biodiversity by design: The attributes of ornamental plants in urban forest parks. Procedia-Soc. Behav. Sci. 2013, 105, 823-839. [CrossRef]

59. Abdullah, J.; Borhan, M.A.-A.; Ahmad, C.B. Orang Asli resettlement in urban environment at Bukit Lanjan, Selangor, Malaysia. Procedia Soc. Behav. Sci. 2015, 201, 71-79. [CrossRef]

60. Jusoh, W.F.A.; Hashim, N.R. Ground arthropods in urban forest fragments, Peninsular Malaysia. Ecol. Environ. Conserv. 2016, 22, 31-40.

61. Norbaiyah, M.Y.; Nazre, M.; Kudus, K.A.; Idrus, N.N.M. Tree health status of mixed species in urban forest of Taman Rimba Alam, Putrajaya, Malaysia. Malays. Appl. Biol. 2017, 46, 91-101.

62. Sabtu, F.S.; Majid, A.H.A. Genetic variation and population structure of the arboreal bicolored ant Tetraponera rufonigra Jerdon from selected urban locations in eastern Penang Island, Malaysia. J. Asia-Pac. Entomol. 2017, 20, 1350-1357. [CrossRef]

63. Karin, B.R.; Freitas, E.S.; Shonleben, S.; Grismer, L.L.; Bauer, A.M.; Das, I. Unrealized diversity in an urban rainforest: A new species of Lygosoma (Squamata: Scincidae) from western Sarawak, Malaysia (Borneo). Zootaxa 2018, 4370, 345-362. [CrossRef] [PubMed]

64. Majuakim, L.; Ling, A.L.M.; Gisil, J. An inventory of flora in urban forests of Universiti Malaysia Sabah Campus, Sabah, Malaysia. J. Trop. Biol. Conserv. 2018, 15, 173-188.

65. Shen, L.W.; Anuar, S.N.B.; Mojiol, A.R. Rapid observational assessment on urban forest trails established at UMS Peak of Universiti Malaysia Sabah. Trop. For. J. 2019, 14, 18-31. 
66. Yin, C.S.; Chai, Y.J.; Carey, D.; Yusup, Y.; Gallagher, J.B. Anthropogenic marine debris and its dynamic across peri-urban and urban mangroves on Penang Island. bioRxiv 2019. [CrossRef]

67. Moser, S.; Avery, E. The multi-scalar politics of urban greening in Forest City, Malaysia. Urban For. Urban Green. $2021,60,127068$. [CrossRef]

68. Pak, H.; Chuah, C.; Yong, E.; Snyder, S. Effects of land use configuration, seasonality and point source on water quality in a tropical watershed: A case study of the Johor River Basin. Sci. Total Environ. 2021, 780, 146661. [CrossRef] [PubMed] 